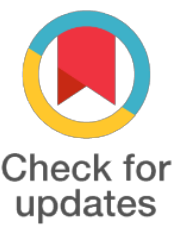

${ }^{*}$ For correspondence:

amira_raudhah@yahoo.com

Competing interests: The authors declare that no competing interests exist.

Received: 2017-04-09

Accepted: 2017-04-29

Published: 2017-09-05

Copyright The Author(s) 2017. This article is published with open access by BioMedPress (BMP).

This article is distributed under the terms of the Creative Commons Attribution License (CC-BY 4.0) which permits any use, distribution, and reproduction in any medium, provided the original author(s) and the source are credited.

\section{Quercus infectoria semi-purified fractions promoted BMP-2, Runx2 and osteopontin expression in human fetal osteoblastic cell line}

\author{
Amira Raudhah Abdullah, Dr. Hermizi Hapidin, Dr. Hasmah Abdullah \\ School of Health Science, Universiti Sains Malaysia, Kubang Kerian, Kelantan 16150, Malaysia
}

\begin{abstract}
Quercus infectoria (Ql) is traditional medicines in Asia which contain many active phytochemical compounds that have the potential to stimulate bone formation. However, the precise mechanism of the therapeutic effect of $\mathrm{Ol}$ on osteoblast has not been elucidated. The present study was carried out to extract the active compound of $\mathrm{Ol}$ through a series of purification in order to obtain semi-purified fractions of $\mathrm{Ol}$ followed by examining its phytochemical profile through liquid chromatography mass spectrometry (LC-MS) as well as to delineate the molecular mechanism of Ol semi-purified fraction-enhanced bone formation by investigating the protein expression of bone morphogenic protein-2 (BMP-2), Runx2 and osteopontin (OPN) in the hFOB 1.19 human fetal osteoblastic cell line. The semi-purified fractions of $\mathrm{Ol}$ were produced in series of column chromatography and thin layer chromatography (TLC) technique. The obtained fractions were then tested in a series of bio-guided assay through MTT assay. Three most potent fractions with lowest $\mathrm{EC}_{50}$ value (Fraction $\mathrm{A}-10.85 \mathrm{\mu g} / \mathrm{ml}$, Fraction B-12.00 $\mu \mathrm{g} / \mathrm{ml}$ and Fraction $\mathrm{C}-11.60 \mu \mathrm{g} / \mathrm{ml}$ ) were selected to be treated with hFOB1.19 cell followed by quantification of BMP-2, Runx2 and OPN protein expression at day 1, 3 and 7. Compound profiling through LC-MS analysis showed that the chosen fractions consist of main active component known as gallic acid that has been showed previously to promote bone formation. Results show that Ql semi-purified fractions increased the activity of BMP-2, Runx2 and OPN at day 1 and day 3 . Meanwhile as the expression of BMP-2 and Runx 2 continue to increase at day 7 , the expression of OPN shows a down regulation at day 7 . Furthermore, the study showed that combination of Fraction $A, B$ and $C$ wit osteoporotic drug (pamidronate) further increase the expression of BMP-2 and Runx2 contrary to OPN expression. These finding demonstrated that semi-purified fraction of $\mathrm{Ol}$ enhanced bone formation through expression of investigated bonerelated marker.
\end{abstract}

\section{Keywords}

Quercus infectoria, Bone Morphogenic Protein-2 (BMP-2), Runx2, Osteopontin, hFOB1.19 cell Funding

\section{Reference}

